\begin{tabular}{|c|l|}
\hline Title & Recent A nomal ous Lightning Occurrences in A laska- the Case of June 2005- \\
\hline Author(s) & Hay asaka, Hiroshi; Farukh, Murad A hmed; Kimura, Keiji \\
\hline Citation & Journal of disaster research, 6(3), 321-330 \\
\hline Issue Date & 2011-11 \\
\hline Doc URL & http://hdl.handle.net/2115/57946 \\
\hline Type & article(author version) \\
\hline File Information & Dr6-3-4586_proofread - OK.pdf \\
\hline
\end{tabular}

Instructions for use 


\title{
Recent Anomalous Lightning Occurrences in Alaska \\ - the Case of June 2005 -
}

\author{
Murad Ahmed Farukh*, Hiroshi Hayasaka*, and Keiji Kimura*
}

\begin{abstract}
Lightning occurred in Alaska an extraordinary number of times 120,000 a year, or 4 times more than average in 2004, 2005, and 2007, starting 500 forest and wild fires. Given the rainless conditions at the time, fires in 2004 and 2005 burned 10\% of Alaska's forests. In 2007, however, fires were suppressed by rainy weather.

To determine the causes of such unusual activity, we analyzed cloud-to-ground (CG) lightning data for the last 22 years, since 1986, radiosonde data measured at Fairbanks, weather maps from various heights, and satellite images. This comprehensive analysis of thunderstorm activity clearly showed weather conditions during the disastrous lightning season of 2005. Yearly, monthly, and daily lightning trends and conditions surrounding ordinary cell thunderstorm formation over Alaska are discussed. Conditions related to the exceptionally large number of occurrences on June 15, 2005, were clarified based on 11 days of weather maps and emagrams and considering a wide variety of weather conditions. The most anomalous lightning conditions occurred when center of thermal low and 500hPa persistent high was in close proximity over Alaska.
\end{abstract}

Keywords: Thermal low, Weather pattern, Persistent high, Emagram, Foehn wind 


\section{Introduction}

This paper discusses Alaskan lightning, the natural igniter and source of Alaskan forest fires, based on weather maps, radiosonde data, satellite images, and other information from the Alaska Fire Service (AFS). Alaskan lightning density is ordinarily very low 0.1-0.8 flashes $/ \mathrm{km}^{2} /$ year with over $90 \%$ of lightning occurring in June and July. So-called “dry” lightning and lightning-caused fires ignite Alaska’s boreal forests. Overall, "lightning” fires burn over 90\% of the state’s annual conflagration areas (Shulski et al. [1]).

Alaskan lightning has not been studied much for 3 reasons: (i) forest fires are the focus of most such research; (ii) Alaskan lightning is mostly due to "ordinary" cell thunderstorms rather than frontal or cyclonic lightning, and most researchers know a lot about lightning, including that in Alaska; and (iii) Alaska’s lightning detection began only in 1976 (Dissing and Verbyla [2]).

To summarize past research, spatial lightning strike patterns and their relationship to elevation and vegetation were studied by Dissing and Verbyla [2], and diurnal lightning strike variability was reported by Reap [3]. Lightning strikes in Alaska were found to be due mostly to convection from surface heating rather than large-scale synoptic forcing (Sullivan [4]; Biswas and Jayaweera [5]; Reap [6]), but small thunderstorms were sometimes associated with shallow convection due to low freezing levels (Ishii et al. [7]; Engholm et al. [8]). McGuiney et al. [9] found that over 2,000 daily lightning strikes occurred in the interior of Alaska when the maximum temperature exceeded $21^{\circ} \mathrm{C}$, and much research has shown lightning and air temperature to be strongly related (Williams [10][11][12][13][14]). Rorig and Furguson [15][16] used radiosonde data to predict "dry" (thunderstorms producing $<2.5$ mm of rain) versus "wet” (thunderstorms producing $\geq 2.5 \mathrm{~mm}$ of rain) lightning. Alaska had an unusual number of disastrous lightning occurrences in 2004, 2005, and 2007, with some 120,000 lightning flashes starting 500 fires a year. It remains difficult, however, to 
find reports in the literature on this activity. According to a report on 2004 lightning by Richmond and Shy [17], some of the unusual lightning in 2004 was caused by (i) a 500hPa strong ridge from $48^{\circ} \mathrm{N}$ latitude toward northwest Alaska and (ii) northeast/east down-sloping winds were strengthened by this unusually strong $500 \mathrm{hPa}$ high. These do not, however, fully explain the phenomenon because they did not fully interpret lightning occurrence conditions in 2004, suggesting that further research was needed to clarify why such unusual lightning occurred.

This study discusses weather conditions and pattern changes causing the most anomalous lightning occurrence in mid-June 2005 based on monthly, daily, and hourly weather data, weather maps for various heights, temperature profiles for different altitudes, lightning distribution maps, and satellite images.

\section{Materials and Methods}

\subsection{Lightning Detection, Study Areas $S_{I}$ and $S_{F}$, and Satellite Observation}

Nine lightning detection sensors have been used in Alaska to detect cloud-to-ground (CG) lightning strikes (Reap [6]) since 1976, and the system was upgraded in 2000. Since interior Alaska has the highest potential for thunderstorms and lightning fires in the state, this lightning detection network was implemented to help prevent fires. Asterisks $\left(^{*}\right)$ in Fig. 1 show lightning detection sensor locations. Sensors record a strike only if it is detected by more than one sensor and the position is determined by triangulation. The largest rectangle in Fig. 1 shows study area $S_{\text {I }}, 806,785 \mathrm{~km}^{2}$ covering north latitude (NL) $62^{\circ}$ to $68.5^{\circ}$ and west longitude (WL) from $141^{\circ}$ to $163^{\circ}$. Lightning detection within this area was assumed to have a positional accuracy of 2-4 km and a detection efficiency of 40-80\% up to 1999 (Dissing and Verbyla [2]). Detection accuracy has been increased to $0.5-2 \mathrm{~km}$ and efficiency to $80-90 \%$ since 2000 without increasing the number of sensors. Within $S_{\mathrm{I}}$, the highest average lightning strike density from May to August 1986 to 2006 was 81.6 X $10^{-3}$ flashes $/ \mathrm{km}^{2} /$ year (Hayasaka 
[18]), located in the boreal forest zone and $80 \mathrm{~km}$ northeast of Fairbanks (NL 6525", WL $\left.146^{\circ} 5^{\prime \prime}\right)$. Fig. 1 shows a smaller white-bordered rectangle of 222,600 $\mathrm{km}^{2}$ of study area $\mathrm{S}_{\mathrm{F}}$ used to show lightning conditions at Fairbanks $\left(62-66^{\circ} \mathrm{N}\right.$ and $\left.142-151^{\circ} \mathrm{W}\right)$. An intermediate dashed-line rectangle shows a 788,075 $\mathrm{km}^{2}$ satellite observation area.

[Insert Fig. 1]

\subsection{Lightning Data}

Daily lightning data from 1986 to 2009 was obtained from the Alaska Interagency Coordination Center (AICC) [19], Bureau of Land Management, AFS, with data missing for 1987 and 1989. AFS data includes coordinates, dates, time, signal strength, polarity, etc., for individual lightning flashes detected from the Bering Strait to the Canadian mountains $\left(135^{\circ} \mathrm{W}\right.$ to $\left.179^{\circ} \mathrm{WL}\right)$ and from Arctic tundra to southeastern coast forest ( $70^{\circ} \mathrm{N}$ to $\left.50^{\circ} \mathrm{NL}\right)$.

\subsection{Weather Data}

Weather data from Fairbanks Airport was chosen as typical of Alaska because it is expected to be the most reliable and has been available longest. While 1986-2009 Fairbanks weather data cannot explain all Alaskan weather changes, it explains most in eastern interior Alaska. Weather data from the Alaska Climate Research Center [20], Fairbanks, and the National Climatic Data Center summary of daily data [21], was analyzed considering weather components of surface, maximum, and dewpoint temperature, sea level pressure, wind speed and direction, and precipitation. To determine thunderstorm variability influenced by weather patterns, we used monthly, weekly, and daily sea level and 925, 850, 700, 500, and 300hPa weather maps from NCEP/NCAR reanalysis data, USA (Kalnay et al. [22]).

\subsection{Atmospheric Sounding Data}

"Radiosonde” (upper air) data for Fairbanks was used because Fairbanks has the only radiosonde station in interior Alaska. While it cannot explain all changes in upper air conditions, it can be used to explain most the weather changes in eastern interior Alaska. 
The last two decades of radiosonde data from ground to the $100 \mathrm{hPa}$ and "Skew-T log-P" diagrams (emagrams) for Fairbanks are from the University of Wyoming webpage [23]. Radiosonde parameters considered were air and dewpoint temperature, geopotential height, wind direction, and relative humidity at 925, 850, 700, 500, and 300hPa.

\subsection{Satellite Images}

Satellite images acquired by Terra and Aqua (NASA-MODIS) for the North America Aeronet Bonanza subset cover from $158^{\circ} 31^{\prime \prime} \mathrm{W}$ to $138^{\circ} 05^{\prime \prime W L}$ and from $61^{\circ} 30^{\prime \prime N}$ to $67^{\circ} 58^{\prime \prime N L}$ [24] were used to identify thunderstorm clouds and their locations and wind direction .

\section{Lightning Occurrence}

\subsection{Alaskan Cell Thunderstorm Model and Conditions}

The mature Alaskan single-cell thunderstorm model in Fig. 2 shows conditions required for thunderstorm formation and resulting lightning.

[Insert Fig. 2]

In studying Alaskan lightning, we found summer lightning to be assisted by two conditions -the temperature at the lifted condensation level (LCL Temp) and freezing point height (FPH). Lightning tends to occur when LCL Temp exceeds freezing or $0^{\circ} \mathrm{C}$ and FPH exceeds 2,000 m, indicating that lightning needs warm conditions $\left(>0^{\circ} \mathrm{C}\right)$ to create vapor, then very small ice particles at higher altitudes. These then formed ice particles, graupel ("soft" hail), or hailstones. Summer lightning thus occurred from the end of May at higher LCL Temp and spread with increasing FPH.

Hot surface air masses rise as "thermals" (rising hot air bubbles) forced upward by intense solar heating on the earth's surface. Cumulonimbus clouds form when thermals accumulate enough moisture at a certain height, ice particles forming within these clouds and growing in rising air currents. Ice particles growing large enough fall as drizzle or raindrops. "Dry" 
lightning” may occur due to dry conditions near the ground, but lightning from the edge of cumulonimbus clouds could ignite forests more easily.

\subsection{Yearly and Monthly Lightning Trends}

In a time series of the total number of yearly May to August lightning from 1986 to 2009 (excluding 1987 and 1989 missing data) in $S_{\mathrm{I}}$ in Fig. 3, 2004, 2005, and 2007 were extreme in total annual lightning within $\mathrm{S}_{\mathrm{I}}$. Compared to 2005, the largest contrast in annual flash count was in 1996, with 13,000 annual occurrences.

[Insert Fig. 3]

Monthly lightning occurrence is also shown in Fig. 3, where different patterns are evident in May through August, is often too sparse to fully clarify monthly differences, but clearly shows that most lightning occurred in June and July. In other trends, 99\% of lightning occurred from May to August, 90\% in June and July, and the most frequent from mid-June to mid-July.

\subsection{Daily Lightning Trends}

Daily lightning from May to August 1986 to 2009 occurred on 34\% of days with 0 and 55\% days with 1-999 flashes, meaning that 0 and 1-999 cases of lightning occupied $90 \%$ of the days from May to August, so we considered the $10 \%$ of occurrences (241 days) of over 1,000 flashes/day as "unusual” in the Alaskan context. The number of lightning occurrences in these 241 days is shown by the bar graph in Fig. 4 .

[Insert Fig. 4]

The three largest peaks since 1986 were recorded in June 2005, with lightning occurring over 13,000 times on June 15 (Fig. 4). Daily lightning occurrence in Alaska shows a systematic diurnal pattern starting at 11:00, peaking at 17:00, and ending at midnight (McGuiney et al. [9]). This indicates that Alaskan thunderstorms are so-called “ordinary” cell thunderstorms.

\section{2005 Historical Lightning Occurrence}


Unusual lightning occurrences in 2004 are partially explained by Richmond and Shy [17] using weather patterns at $500 \mathrm{hPa}$. In the following sections, we comprehensively analyzed the background of the exceptionally large number of lightning flashes $(13,027)$ on June 15 , 2005, based on details in daily and hourly data.

\subsection{Changes on the Most “Anomalous" Day for "Pre” and "Post” Lightning}

Daily changes in surface and elevated weather conditions from June 8 to 18 are shown in

Table 1 to better explain the exceptionally large number of lightning occurrences on June 15 .

Table 1 compares the numbers of lightning occurrences for $S_{I}$ and $S_{F}$.

[Insert Table. 1]

As shown in Table 1, study area conditions for high lightning occurrence involved (1) intense solar radiation $\geq 6 \mathrm{~kW}$-hr/ $\mathrm{m}^{2}$ for 9 days raising surface temperatures; (2) maximum temperature $\left(T_{\max }\right)$ of $30^{\circ} \mathrm{C}$, a $5^{\circ} \mathrm{C}$ higher than mean June temperatures could induce lifting by rapid upward warm air mass movement, creating lower atmospheric instability; (3) the temperature difference $(\Delta \mathrm{T})$ between $850 \mathrm{hPa}$ and $500 \mathrm{hPa}$ of $30^{\circ} \mathrm{C}$, a $3^{\circ} \mathrm{C}$ higher than the mean June $\Delta \mathrm{T}$ could produce higher instability from middle to upper layers; (4) the temperature difference (dew point depression, $\mathrm{DD}_{850}$ ) between the dew point and air at 850hPa below $6^{\circ} \mathrm{C}$ indicates the presence of high moisture and humidity; (5) the temperature at LCL above $3^{\circ} \mathrm{C}$ and FPH above 2,700 $\mathrm{m}$ could contribute to the development of thunderstorms; (6) updrafts could cause precipitation and ice particles could cause downdrafts mostly accompanied by thunderstorms; and (7) a relatively higher >100 convective available potential energy (CAPE), and higher negative <-15 convective inhibition (CIN) could induce higher atmospheric instability.

Other conditions taken from radiosonde data analysis for the largest number of lightning occurrences on June 15 were (i) middle layer instability developing due to relatively warmer condition $\left(>11^{\circ} \mathrm{C}\right)$ at $850 \mathrm{hPa}$, (ii) the amount of precipitable water for entire sounding of 20 
mm aiding thunderstorm cloud formation, (iii) raised geopotential heights suggesting the formation of upper layer high-pressure systems, and (iv) a relatively lower $<0$ Showalter index (SI) and LIFTED index (LI) implying unstable conditions in the middle and upper atmosphere.

\subsection{Alaskan "Thermal low"}

\subsubsection{Vertical Structure - Skew-T Log-P Diagram (Emagram)}

Two Skew-T log-P diagrams (emagrams) for June 12 and 15 are shown in Fig. 5 for the vertical formation of an Alaskan "thermal low" and conditions aloft for peak lightning, 13,027 flashes on June 15. Fig. 5 also shows the vertical profile of the environmental temperature $\left(T_{e}\right)$ and dewpoint temperature $\left(T_{d}\right)$ for June 12 and 15. A comparison of these clearly shows conditions of an Alaskan thermal low, two different pressure height changes on June 12 and 15 (at left in Fig. 5). The considerable depression near the surface layer below $1,000 \mathrm{~m}$ (a $40 \mathrm{~m}$ depression at 1,000hPa) in the June 15 emagram shows the growth of a thermal low mainly due to significant $T_{e}$ rises in the atmosphere below $3,000 \mathrm{~m}$ (a $10^{\circ} \mathrm{C}$ rise near the ground). A considerable rise in pressure in middle and upper layers above 1,000 m (a $20 \mathrm{~m}$ rise at $700 \mathrm{hPa}$ ) shows the growth of a high-pressure system. The concomitant occurrence of these two features aloft is typical of an Alaskan thermal low, a relatively weak vertical structure compared to the typical thermal low's pressure gradient of desert areas (Markell [25]).

[Insert Fig. 5]

Four other changes are to be noted in atmospheric conditions in Fig. 5:

(1) A $T_{e}$ drop of $5^{\circ} \mathrm{C}$ in middle layers at 5,000-7,000 $\mathrm{m}$ increasing instability energizes deep convection to charge separation and lightning and strongly affects CAPE. 
(2) Wind direction changes in the middle and upper layers within 2,000 m and 11,000 m. This change in wind direction from easterly to northerly may be a reason for the $T_{e}$ drop between 5,000 and 7,000 m.

(3) Table 1 shows a $\Delta \mathrm{T}$ increase of $6^{\circ} \mathrm{C}$ and a $\mathrm{DD}_{850}$ increase of $3^{\circ} \mathrm{C}$, representing very unstable, moist upper layers. $\Delta \mathrm{T}$ and $\mathrm{DD}_{850}$ are commonly applied to classify convective days as “dry" and "wet” in the North American Pacific Northwest (Rorig and Ferguson [15][16]).

(4) Table 1 shows CAPE on June 15 to be 423 and CIN to be -23, suggesting the usual higher atmospheric instability. Other indices such as SI (-0.6) and LI (-2) indicate highly unstable atmosphere.

\subsubsection{Horizontal Structure}

\section{(1) Lows and Highs at SLP and 500hPa Height}

Thermal lows on surface weather maps from June 14 to 16 are shown in Fig. 6. The high at 500hPa on weather maps from June 14 to 16 are shown in Fig. 7. L in Figs. 6 and 7 shows the center of a relatively low-pressure and $\mathrm{H}$ a relatively high-pressure.

Alaska summer weather patterns typically involve the so-called thermal low/ocean high. This, in turn, mainly features stagnant weak lows over a warm interior and high-pressure over the north Pacific. Fig. 6 clearly shows a thermal low/ocean low pattern, suggesting that one cause of the greatest lightning peak June 15 was an ocean low supplying moisture to interior Alaska from surrounding oceans. Another pattern is a high over the Beaufort Sea north of Alaska bringing cool air masses into interior Alaska from the Arctic Ocean.

The thermal low over Alaska began developing June 8 when an "orographic" low detached from an Aleutian low and developed over the south Alaska Range slope on June 8. The next day, an independent thermal low near Fairbanks appeared, lasting until June 11. On June 12, a new thermal low over Mayo, Yukon, Canada, appeared. On June 13, the thermal low near Fairbanks reappeared, lasting until June 14. On June 15, the thermal low center moved back 
to Mayo, finally moving east of the Brooks Range on June 16. These complicated movements and the development of the thermal low center may be affected by weather conditions in interior Alaska and surrounding oceans.

[Insert Fig. 6]

[Insert Fig. 7]

In addition to the low near the surface, the Alaskan thermal low formed a high above 900hPa (Fig. 7). From June 8, a ridge from the Canadian side developed over the Canadian border. The next day, a detached high centered over the Mackenzie Mountains, Canada, occurred, and its center moved over the Richardson Mountains, Canada, on June 10, then over Old Crow, Canada, on June 11. On June 12, the center of this high continued westward, reaching the west Brooks Range, developing further there and lasting until June 15. From June 16, this high gradually dissipated, although a ridge from the Gulf of Alaska to the Chukchi Sea was still observable on June 17 and 18.

Based on the above movement and development of the thermal low and upper high, we concluded that lightning could become atypical when centers of both a thermal low and an upper high moved across Alaska and developed further. Two cases from June 8 to 18, 2005, were as follows:

(i) On June 11, unusual lightning 7,357 flashes was observed when both thermal low and upper high centers were close together above the Brooks Range on June 11.

(ii) The three days from June 14 to 16 also had unusual lightning 6,898, 13,027, and 9,831 flashes, as shown in Fig. 9, when the thermal low center moved steadily across Alaska while the upper high center remained stationary above the west Brooks Range.

For the same period during typical years, thermal lows commonly formed in Alaska, but the existence of a north Pacific Ocean low and the close proximity of both thermal low and $500 \mathrm{hPa}$ high centers over Alaska is unusual. 


\section{(2) Temperature Structure at $500 \mathrm{hPa}$}

Typical vast, warmer air masses over Alaska at 500hPa are shown in Fig. 8. We use the term “warmer air mass” because we found such masses mostly surrounded by cooler air masses over Alaska as shown in Fig. 8, which also shows sharp temperature gradients in all directions. A temperature difference of $10^{\circ} \mathrm{C}$ between center of warmer masses over Alaska and cooler masses over Beaufort Sea occurred. The warmer air mass's temperature averaged $3-4^{\circ} \mathrm{C}$ higher than during the same period in years with usual lightning, so we postulated that vast, warmer air masses and sharp temperature gradients in this warmer zone indicated enhanced instability.

[Insert Fig. 8]

On June 8, a warmer air mass centered over Mayo, Yukon, Canada formed, then moved north on June 9. A detached warmer air mass centered over Fort Yukon formed on June 10. From June 11 to 13, the warmer air mass covered most of the Brooks Range and was moving gradually west. On June 14 and 15, a warmer air mass centered over the Baird Mountains formed and expanded northwest to the Chukchi Sea and southwest to the Alaska Range. By June 16, the warmer air mass over Alaska had disappeared.

As shown in Fig. 8, the temperature over Fairbanks dropped from $-17^{\circ} \mathrm{C}$ on June 14 at 500hPa, to $-18^{\circ} \mathrm{C}$ on June 15. The emagram in Fig. 5 also shows this drop within a 5,0007,000 m height, ascribable mainly to a northern wind flow and primarily increasing instability possibly contributing the unusual lightning occurrence.

A comparison of Fig. 7 with Fig. 8 clearly shows the center of both the upper high and warmer air mass over the same area from June 14 until June 16. This indicates the need, when discussing lightning occurrence, to focus more on warmer air mass development as an indicator of increased instability over Alaska.

\subsection{Lightning Distribution}


To identify air streaming into interior Alaska, a prerequisite for thunderstorm formation, we analyzed $\mathrm{U}-\mathrm{V}$ wind at $700 \mathrm{hPa}$ and $850 \mathrm{hPa}$ of the 2.5 degree grid using NCEP/NCAR reanalysis data. Such an air inflow could not be clearly established, however, so, alternatively, we used Alaska lightning distribution maps from AICC of AFS [19] as shown in Fig. 9 to understand details of the moisture supply to interior Alaska and terrain effects on the simultaneous formation of lightning clouds such as cumulonimbus and towering cumulus.

[Insert Fig. 9]

Daily June 2005 lightning distribution maps show that dispersed lightning flashes started from June 10 mainly on southern Brooks Range slopes and near the Alaska pipeline in the north and northeast mountain areas near Fairbanks, the Ray Mountains, and east of the Yukon River estuary. These indicate that moisture had already reached interior Alaska from both the southeast and southwest. On June 11, significant lightning 7,357 flashes were seen mainly in central interior Alaska and on the southern Brooks Range slopes. An Alaskan thermal low and a low over the Gulf of Alaska could induce moisture to flow from the Aleutian Islands into interior Alaska at this point. The next day, lightning became active on south Brooks Range slopes, and lightning near Fairbanks was high on June 13. On June 14, unusual lightning occurred between McGrath and Ruby. On June 15, the most unusual lightning strikes occurred all over interior Alaska other than the Fort Yukon area and even on the south Alaska Range slope. The next day, the lightning migrated northeast.

\subsection{Cumulonimbus Clouds and Foehn Wind Observation by Satellite}

On June 12 and 14, 2005, the Aqua satellite clearly caught relatively large clouds such as cumulonimbus forming over the southeast and southwest mountain areas west and northeast of Fairbanks and on the south slopes of the eastern Brooks range, as shown in Fig. 10.

[Insert Fig. 10] 
Fig. 10 also shows northerly and easterly June 14 winds from the direction of forest fires. After passing the mountain range, northeasterly wind creates a dry, hot, gusty down-sloping foehn wind leeward of the mountains. High daily maximum temperatures of $30^{\circ} \mathrm{C}$ during the 10-day period in mid-June 2005 were $5^{\circ} \mathrm{C}$ higher than mean values and may have resulted due to intense solar radiation of $\geq 6 \mathrm{~kW}-\mathrm{hr} / \mathrm{m}^{2}$ for 9 days in mid-June and due to weak foehn phenomena effects created by down-slope winds from the north and east.

\section{Conclusions}

An analysis of June 8 to 18 weather conditions, including disastrous lightning 13,027 flashes/day on June 15, 2005, clearly show that maximum unusual lightning occurred under the following conditions:

(1) The most anomalous lightning situation 13,027 flashes/day on June 15, 2005, occurred when a thermal low center moved steadily across Alaska while an upper high center remained stationary over the western Brooks Range.

(2) The third largest amount of daily lightning 7,357 flashes/day occurred on June 11 among the 11 days from June 8 to 18 when centers of the thermal low and upper high were observed over the Brooks Range on June 11.

(3) Differences between the first (13,027/day on June 15) and third (7,357/day on June 11) largest lightning occurrences may have been due to enhanced instability through wind direction changes from east to north enabling colder air aloft to flow from the north toward interior Alaska.

(4) An unusual surface weather pattern of a high over the Beaufort Sea - a thermal low over the central Alaska - and a low over the Gulf of Alaska occurred in June 2005. With this combination of surface weather patterns, the Alaskan thermal low developed and persisted for 10 days. 
(5) The Alaskan thermal low also showed both low-pressure formation near the ground and high-pressure formation in upper atmospheric layers similar to desert-area thermal lows.

(6) A vast warmer air mass with sharp temperature gradients along its edges forming over interior Alaska provides a source of instability possibly enabling thunderstorms to grow in size and intensity.

(7) In mid-June 2005, maximum air temperatures of $30^{\circ} \mathrm{C}$ were $5^{\circ} \mathrm{C}$ higher than usual persisted for 10 days and may have been created by the effect of weak foehn phenomena due to prevailing dry northerly and easterly winds. 


\section{Acknowledgements}

We sincerely thank, first, the Physical Science Division, Data Management of NOAA, Boulder, Colorado, USA; second, the Department of Atmospheric Science, University of Wyoming; third, the Alaska Interagency Coordination Center, Bureau of Land Management, Alaska Fire Service; fourth, MODIS (Terra: EOS AM, and Aqua: EOS PM) of NASA, USA; and fifth, the Alaska Climate Research Center, NOAA, for an immense number of reliable datasets and resulting stimulating findings encouraging our research on this issue. We also express our gratitude to Earle R. Williams of the Massachusetts Institute of Technology, Cambridge, MA, USA, for his invaluable scholastic comments and suggestions for improving this paper. 
(I)

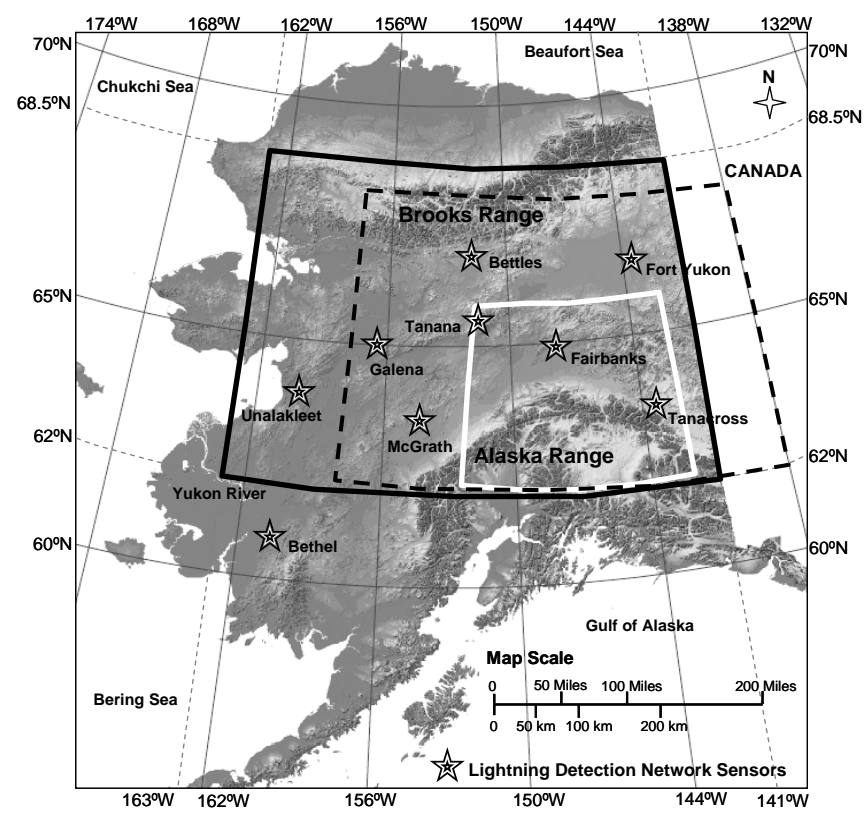

Fig. 1. Lightning detection network sensors, study areas $S_{\text {I }}$ (largest rectangle) and $S_{F}$ (smallest rectangle), and satellite observation area (dashed lines) in Alaska

(II)

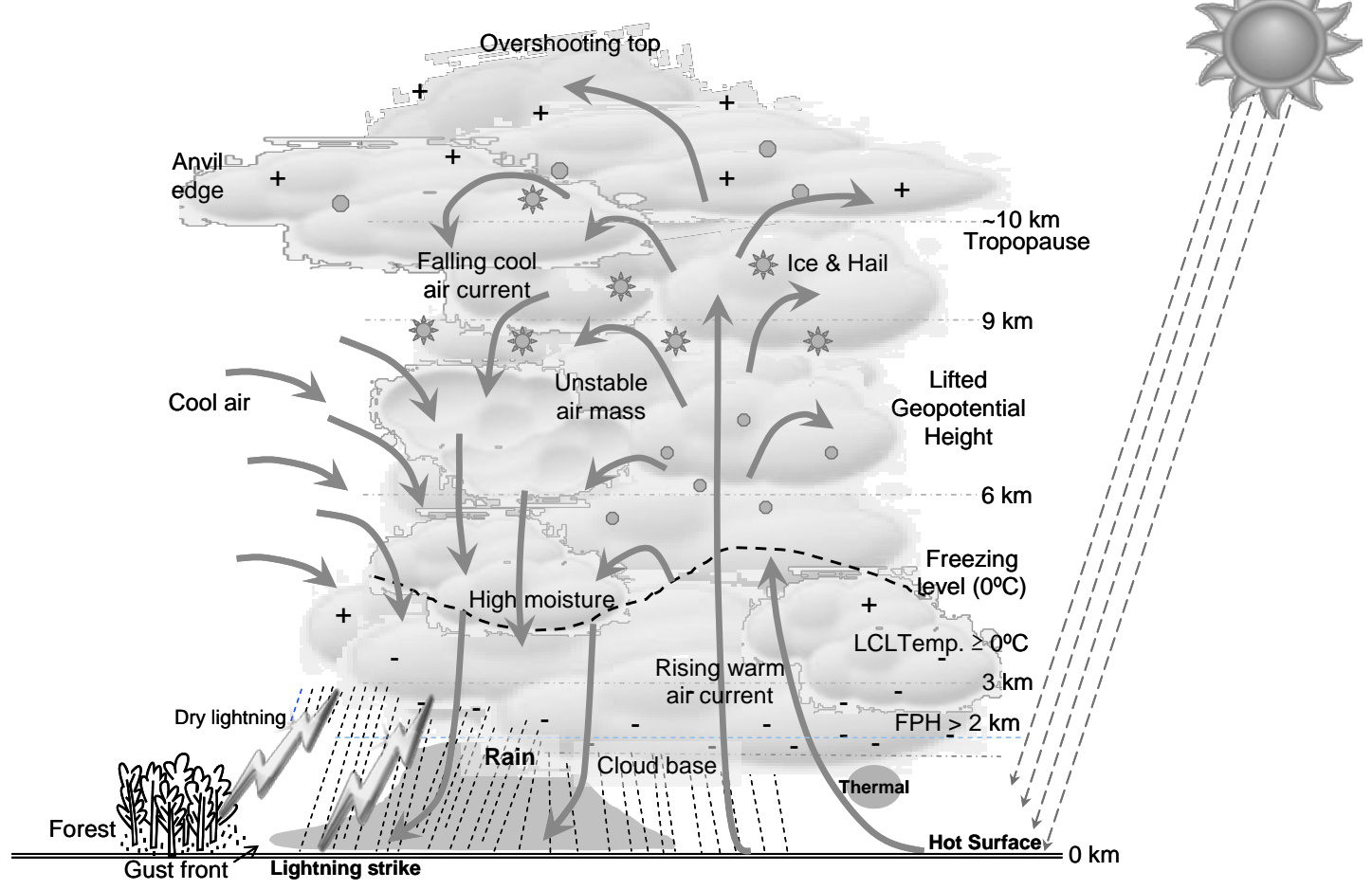

Fig. 2. Model of a mature, single-cell Alaskan thunderstorm 
(III)

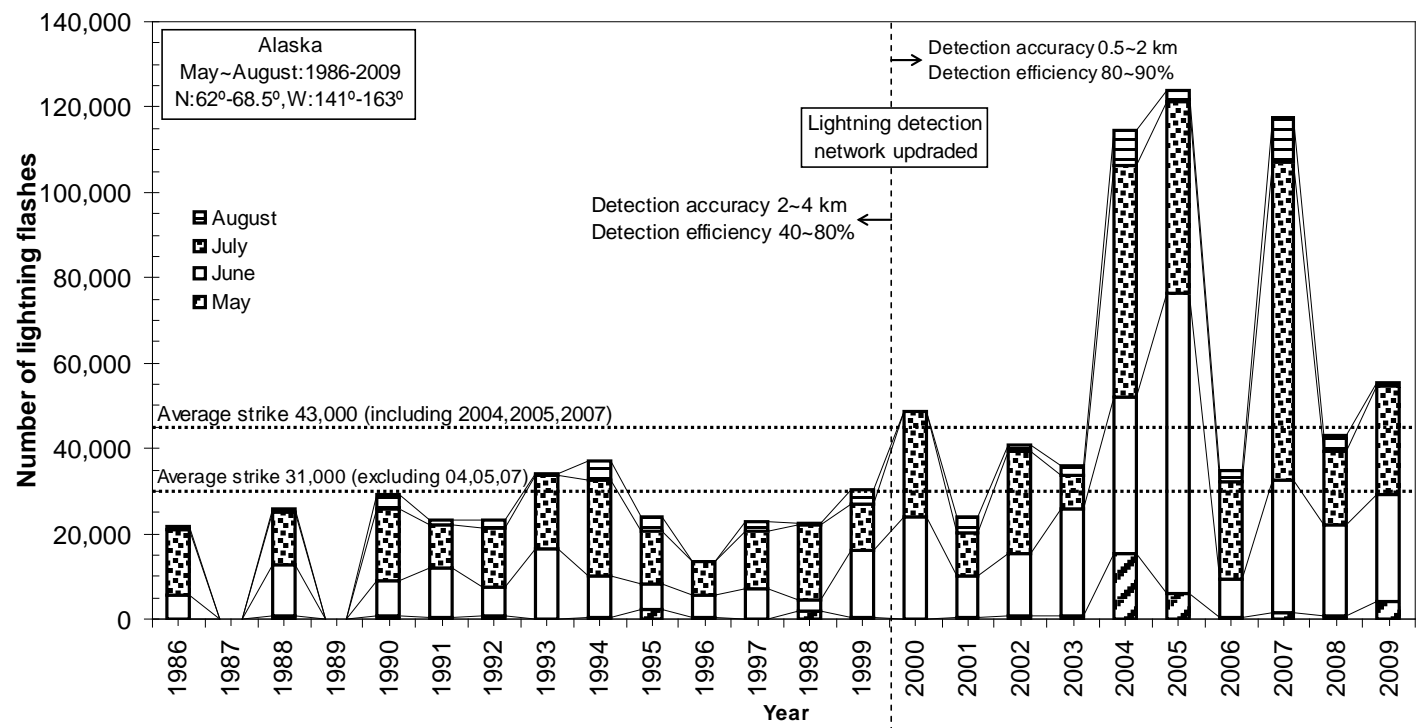

Fig. 3. 1986 to 2009 yearly and monthly lightning occurrence in the $\mathrm{S}_{\mathrm{I}}$ study area of Alaska
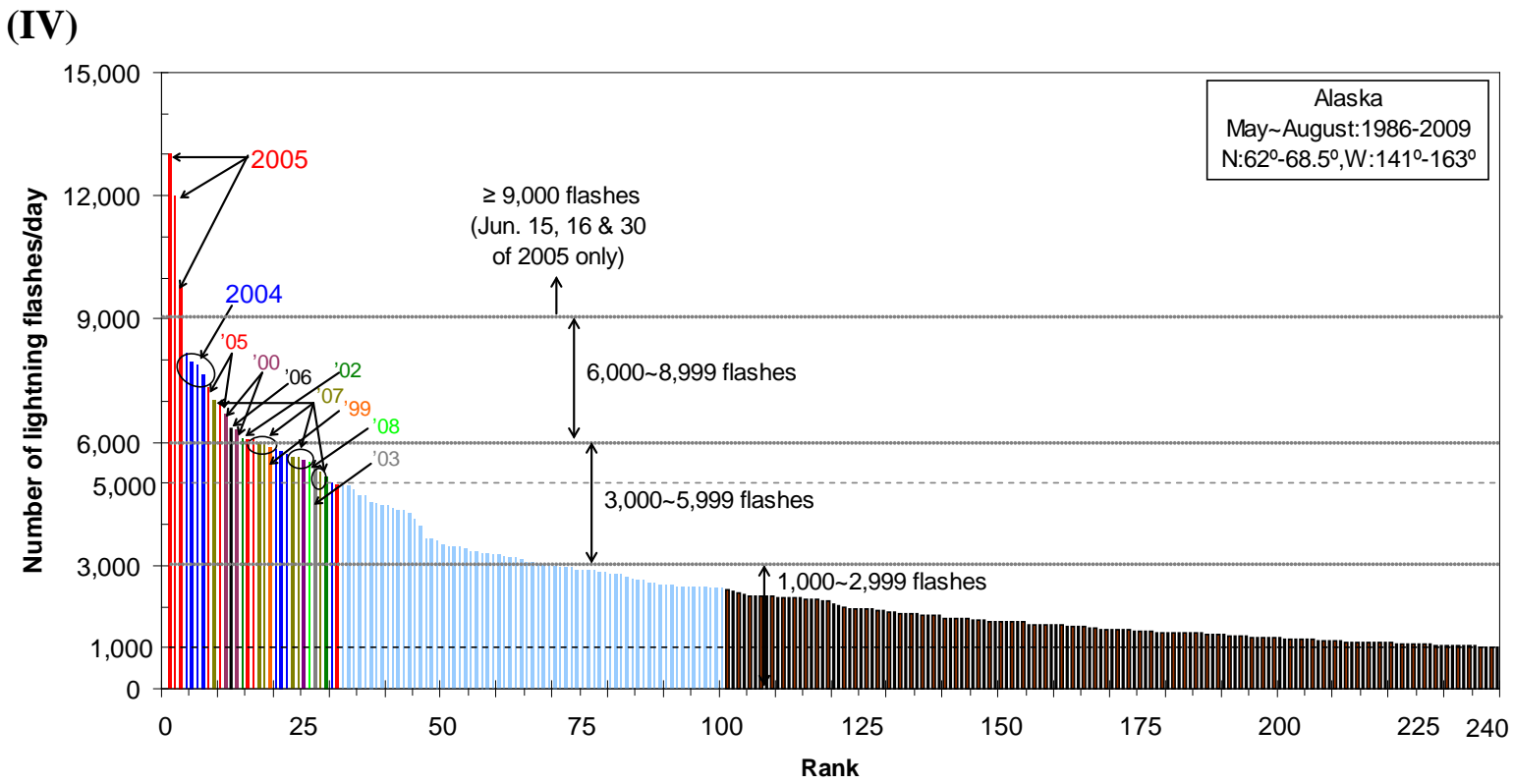

Fig. 4. Daily lightning trends from May to August 1986 to 2009 
(V)
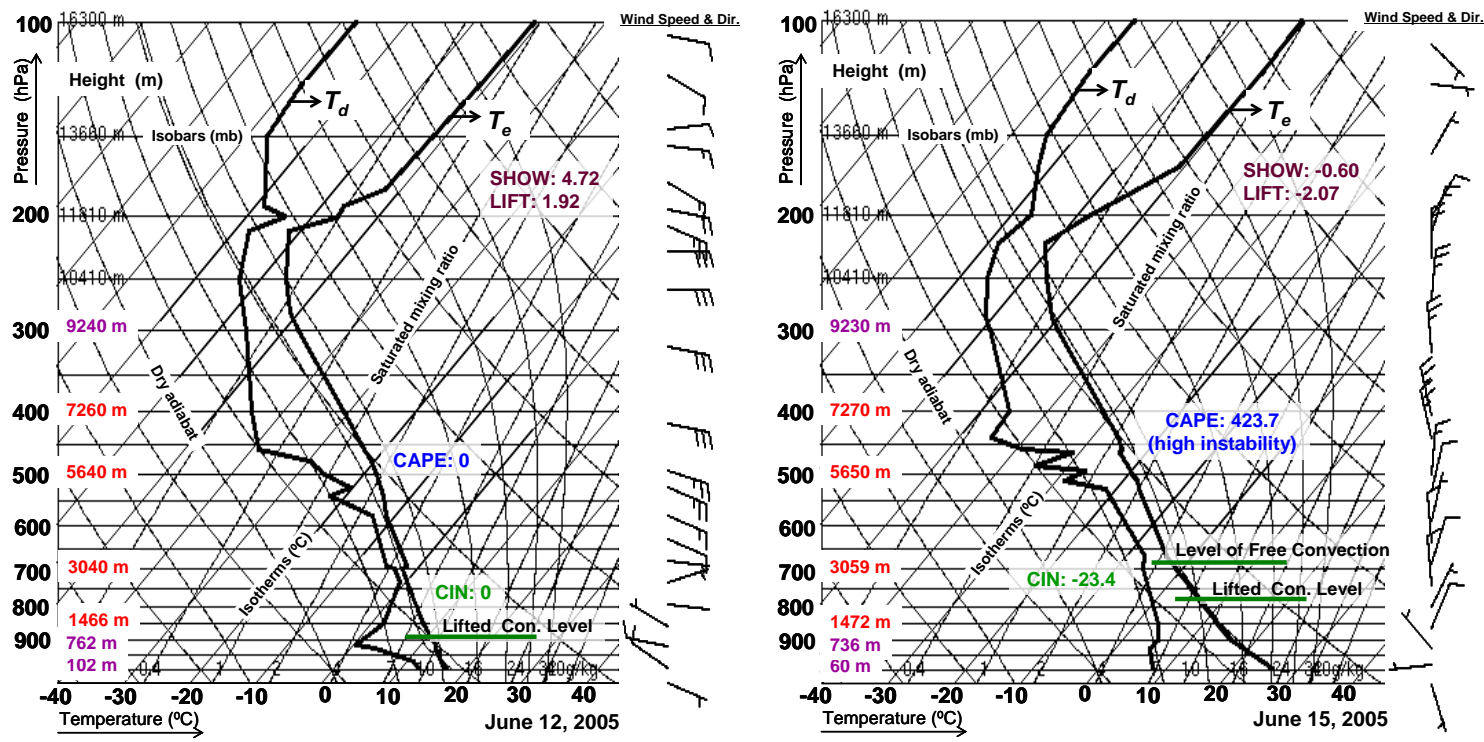

Fig. 5. Emagrams of vertical profiles of temperature, pressure height, etc., on June 12 (left) and 15 (right), 2005

(VI)

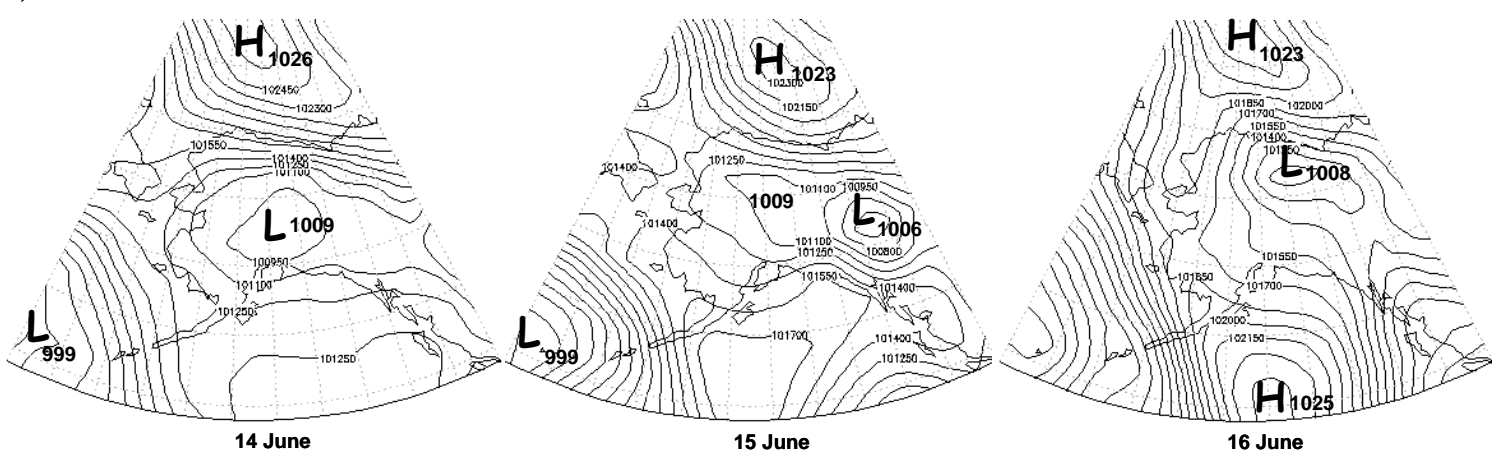

Fig. 6. Alaskan thermal low movement from June 14 to 16, 2005

(VII)

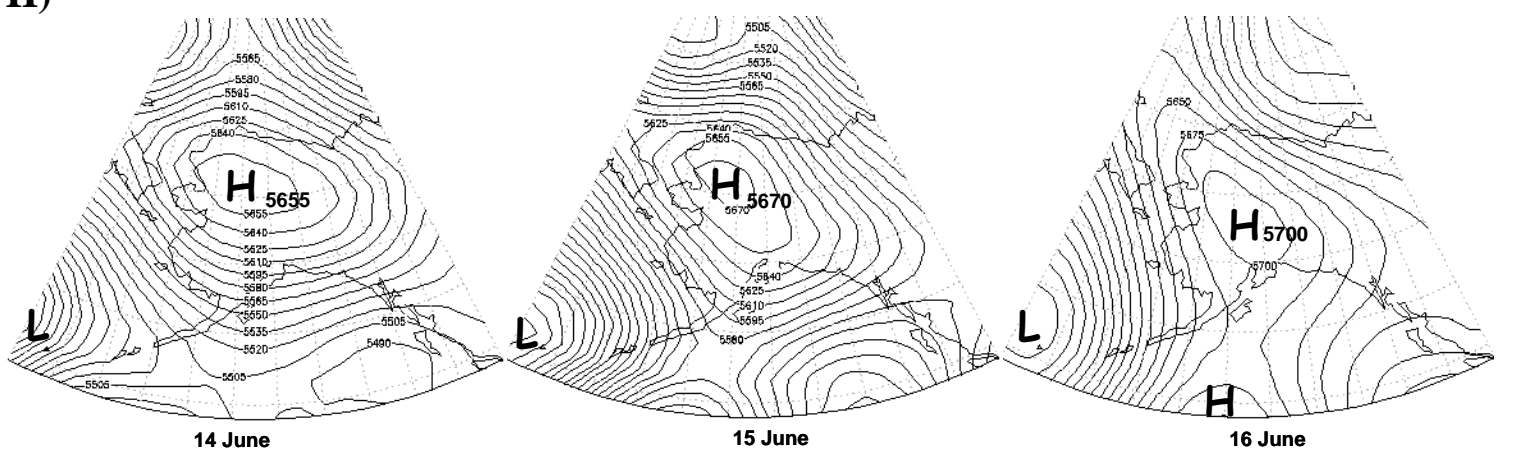

Fig. 7. High at 500hPa height over Alaska from June 14 to 16, 2005 


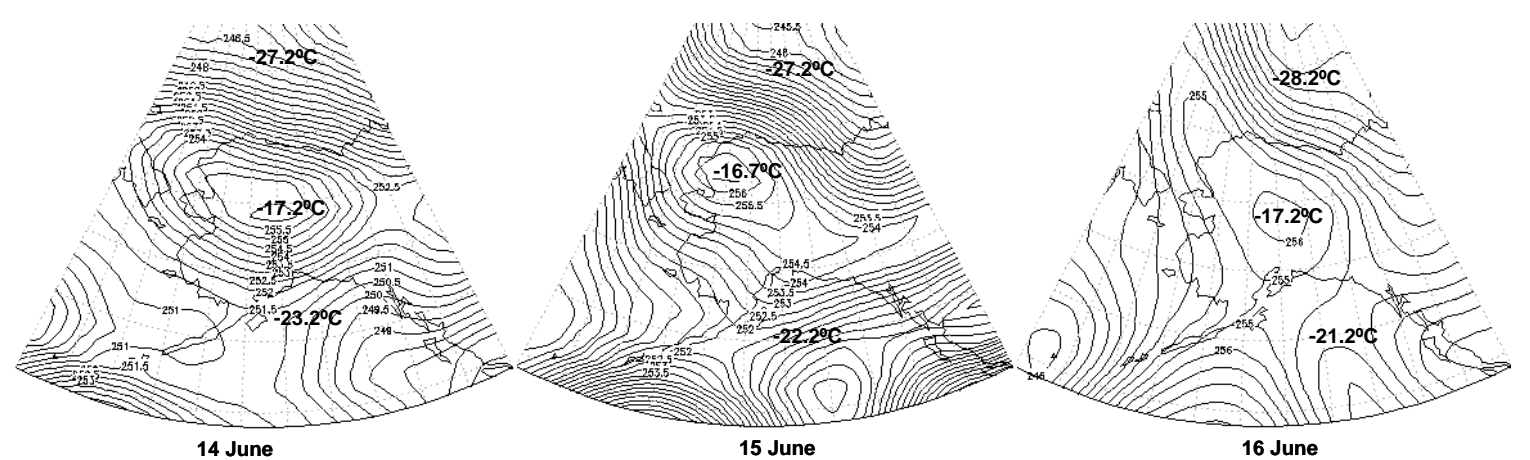

Fig. 8. Warmer air masses at 500hPa height over Alaska from June 14 to 16, 2005

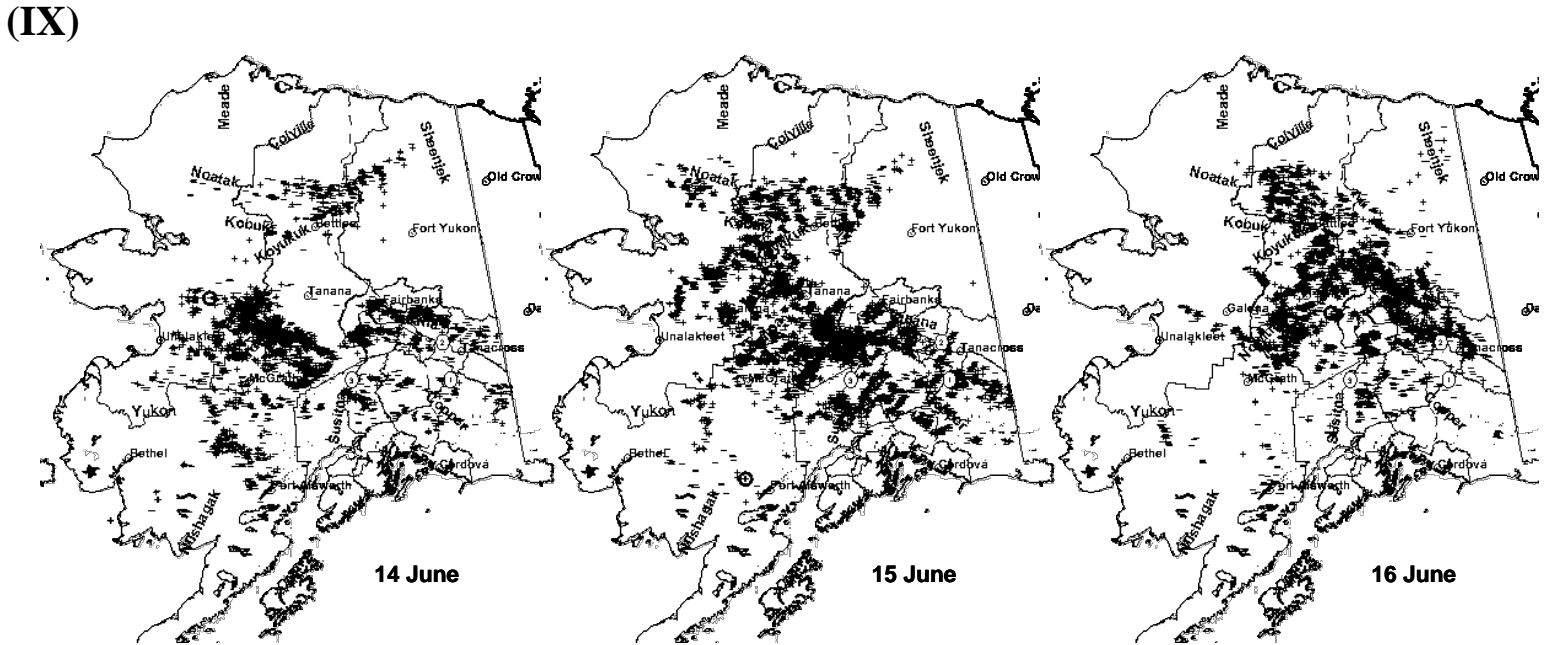

Fig. 9. Alaska lightning distribution maps for June 14-16, 2005

(X)

Fig. 10. Satellite images of cumulonimbus-like clouds and wind direction across Alaska on

June 12 (left) and 14 (right), 2005

Table 1: Weather conditions at the surface and aloft from June 8 to 18, 2005

\begin{tabular}{|c|c|c|c|c|c|c|c|c|c|c|c|}
\hline \multirow{2}{*}{ Day } & \multirow{2}{*}{$\begin{array}{l}\text { Solar Rad. } \\
\left(\mathrm{kW}-\mathrm{hr} / \mathrm{m}^{2)}\right.\end{array}$} & \multicolumn{4}{|c|}{ Temperature $\left({ }^{\circ} \mathrm{C}\right)$} & \multirow{2}{*}{$\begin{array}{l}\text { Precip. } \\
\text { (mm) }\end{array}$} & \multirow{2}{*}{$\begin{array}{l}\text { FPH } \\
(\mathrm{m})\end{array}$} & \multicolumn{2}{|c|}{ Instability indices } & \multicolumn{2}{|c|}{ Lightning strikes } \\
\hline & & Max. & $\Delta \mathbf{T}$ & $\mathrm{DD}_{850}$ & LCL & & & CAPE & CIN & $\mathrm{S}_{\mathrm{I}}$ & $S_{F}$ \\
\hline 8 & 6.3 & 26.7 & 29.1 & 16.0 & -0.7 & 0.00 & 2,614 & 0 & 0 & 1 & 0 \\
\hline 9 & 6.3 & 30.0 & 31.5 & 15.0 & 1.0 & 0.25 & 2,835 & 78 & -64 & 183 & 36 \\
\hline 10 & 7.0 & 30.6 & 31.3 & 9.0 & 3.0 & 1.27 & 3,017 & 145 & -72 & 626 & 106 \\
\hline 11 & 6.7 & 31.1 & 29.3 & 6.0 & 6.4 & 4.06 & 3,076 & 520 & -18 & 7,357 & 1,793 \\
\hline 12 & 3.7 & 22.8 & 25.7 & 6.0 & 9.3 & 3.81 & 2,705 & 0 & 0 & 4,354 & 997 \\
\hline 13 & 6.0 & 29.4 & 27.7 & 4.2 & 10.1 & 2.29 & 2,818 & 898 & 0 & 3,328 & 1,261 \\
\hline 14 & 7.4 & 31.7 & 31.3 & 12.0 & 2.6 & 0.00 & 2,903 & 98, & -25 & 6,898 & 1,266 \\
\hline 15 & 6.6 & 31.7 & 31.5 & 9.0 & 3.3 & 4.57 & 2,950 & 424 & -23 & 13,027 & 3,232 \\
\hline 16 & 6.5 & 30.0 & 28.9 & 7.0 & 5.8 & 0.25 & 2,990 & 321 & -27 & 9,831 & 3,139 \\
\hline 17 & 6.0 & 28.3 & 29.7 & 9.0 & 10.0 & 0.51 & 2,895 & 1062 & -27 & 1,116 & 493 \\
\hline 18 & 4.4 & 25.0 & 22.7 & 8.0 & -0.3 & 5.59 & 3,242 & 0 & 0 & 0 & 0 \\
\hline
\end{tabular}

$\left[\Delta \mathrm{T}\right.$ : temperature difference between $850 \mathrm{hPa}$ and $500 \mathrm{hPa} ; \mathrm{DD}_{850}: 850 \mathrm{hPa}$ dew point depression; LCL: Lifted condensation level; FPH: Freezing point height; CAPE: Convective available potential energy; CIN: Convective inhibition; $\mathrm{S}_{\mathrm{I}}$ : Study area $\left(62-68.5^{\circ} \mathrm{N}\right.$; $\left.141-163^{\circ} \mathrm{W}\right)$; $\mathrm{S}_{\mathrm{F}}$ : Fairbanks area $\left.\left(62-66^{\circ} \mathrm{N} ; 142-151^{\circ} \mathrm{W}\right)\right]$ 